\title{
Do Female Executives Play the Same Role in Determining Firm Performance Across Industries in China?
}

\author{
Xinyue Zhang ${ }^{*}$, Changzheng Zhang \\ School of Economics \& Management, Xi'an University of Technology, Xi'an, China \\ *Corresponding author.Email: zxy_xut@163.com
}

\begin{abstract}
Taking 9416 firm-year observations from 856 A-share listed companies in China over 2006-2016 as the research sample, the paper concentrates on female executives' performance consequences and provides comparative investigations on such consequences across industries. In terms of industry perspective, female-friendly, female-neutral and female-discriminative industries are identified, in which enterprises respectively enjoy positive, zero and negative performance consequences of female executives. In general, female-friendly industries have the characteristics of consumer-oriented, while female-discriminative industries have the characteristics of high-growth or high-tech.
\end{abstract}

Keywords: Female executives, Firm performance, Listed companies, Industry effects, China.

\section{INTRODUCTION}

With the progress and development of society, the economic status of Chinese women has been gradually improved. More and more females have better chances and abilities to participate in various economic activities in China. They break the glass ceiling and enter into the top management team of the company by making remarkable achievements. In this case, how the female executives determine firm performance is a research topic of great significance in China. It's not surprising that western scholars have paid much earlier attention to this issue and given more abundant research contributions than their Chinese peers.

Four main research streams have been identified regarding to this research topic, including upper echelon theory, principal-agent theory, Resource dependency theory and assimilation theory.[1][2][3][4] Based on the theoretical perspectives above, amounts of research contributions have been made by the scholars all across the world. Up to now, there is no consensus conclusion in this field.[5] The influence of female executives on firm performance presents many conflicting conclusions, such as positive, negative, non-linear or zero effect. Therefore, the research on the performance consequences of female executives still needs to be further carried out. In view of the diversity of current research results on this topic, the performance consequences of female executives should be the contingent effects rather than the absolute ones. Therefore, we should consider the external environmental factors in which female executives play a role in order to open the "black box" of the relationship mechanism between female executives and firm performance.

Previous studies have shown that industry characteristics are the most comprehensive environmental factor, which can significantly restrict or promote the formation of enterprise performance. A few studies argue that there is an implicit matching relationship between industry characteristics and female characteristics, and there are different possibilities for women's specialized human capital and psychological capital which are different from those of their male peers in different industries to play effectively. Hence, it is necessary to explore and compare the performance consequences of female executives in different industries in China.

Based on the above discussion, this study will explore and compare the relationship between female executives in different industries in China and corporate performance. In theory, the paper enriches the research on the effect of female executives and expands the 
boundary of the research on the mechanism of determining corporate performance. In practice, it provides decision-making basis for enterprises in different industries to strengthen the participation of female executives effectively, helps enterprises to improve the gender diversity of senior management team properly, and enhances the improvement of enterprise performance.

\section{LITERATURE AND HYPOTHESIS}

Researchers believe that gender diversity may be particularly valuable during economic downturns, because the gender diversity executive committee reduces volatility and increases balance throughout the business cycle. However, more and more studies have reached mixed results on female executives' performance consequences. Such a fact demands the scholars for searching critical contingent variables that can clarify the "black-box" of the relationship between the two.

In amounts of studies, industry has a significant impact on many aspects of the company's operation. For example, it has been found that he level of sustainability reporting positively influence the operational, financial and market performance of the manufacturing industry, while negatively affect the operational, financial and market performance in the banking sector[6]. In some other studies having much closer associations with the issues of female executives, the leadership styles, behavioral patterns and even the risk aversion degrees of the female executives vary across industries[7]. Therefore, we guess that industry has essential effect on female executives' performance consequences.

Some studies investigating the relationships between female executives and firm performance among various industries have found the opposite relationships between the two by simultaneously adopting multiple industries in a given study. [9][10] Holding the view that industry differences have different requirements for the characteristics and abilities of enterprise managers, H1 can be proposed:

H1: There are significant differences among female executives' performance consequences across industries in China.

\section{METHODOLOGY}

\subsection{Research Sample}

In this paper, the 2006-2016 China A-share non-financial listed companies are used as the initial sample frame, and the research samples are selected strictly according to the following criteria:

(1)To eliminate the listed companies that have been ever publicly punished during the sample years; (2)To

eliminate the listed companies ever marked with ST or PT during the sample years, since they were associated with abnormal financial conditions;(3) To remove the listed companies ever with singularity data during the sample years (e.g., the salary gap between executives and employees is negative, the salary of employees is lower than the local minimum wage standard, and the product of the return on assets and earnings per share is negative, etc.); (4)To remove the listed companies that have ever failed to disclose the needed research data during the sample years; (5)To exclude the listed companies that have ever experienced significant asset restructuring during the sample years.

The data mainly comes from the annual reports of listed companies disclosed by China Information Network and Juchao Information Network. According to the above procedures, finally obtained panel data of 11 years of 9416 company observations of 856 A-share listed companies as the final research sample.

\subsection{Variables}

(1) Explained variables: Referring to Giraldez-Puig[12] and Peni[13], this paper adopts return on equity (ROE) to measure firm performance. ROA is the alternative measure.

(2) Explanatory variable: Referring to Chen et al. [14], considering the specialized governance features of Chinese listed companies, this paper uses the proportion of female executives relative to the total size of the top executives team (also including the directors and supervisors) as the measure of female executives' participation (FEP). Female executives include the female top managers, the female directors and the female supervisors.

(3) Control variables: Seven variables are chosen as the control variables: firm size (FS, Natural logarithm of the company's main business income), firm age (FA), CEO duality (CDU), Ratio of independent directors (RID), Equity concentration (EC, Ratio of the first largest shareholder's share relative to the total share), Size of top executives team (STET), Executive-employee pay gap (EEPG, The natural logarithm of the difference between the average cash compensation for executives and the average cash compensation for employees).

\subsection{Models}

In order to test $\mathrm{H} 1$, this paper constructs Model (1). $R O E_{\text {it }}=\beta_{0}+\beta_{1} F E P_{\text {it }}+\beta_{2} F S_{\text {it }}+\beta_{3} F A_{\text {it }}+\beta_{4} C D U_{\text {it }}+\beta_{5} R I D_{\text {it }}$ $+\beta_{6} E C_{\mathrm{it}}+\beta_{7} S T E T_{\mathrm{it}}+\beta_{8} E E P G_{\mathrm{it}}+\varepsilon_{\mathrm{it}}$ 


\section{EMPIRICAL RESULTS}

\subsection{Descriptive Statistics and Correlation Analysis of Variables}

The results of variable descriptive statistics and correlation analysis are shown in Table 1. There are significant correlations between firm performance and control variables, which initially shows that the selection of control variables is reasonable. Moreover, the correlation coefficients among main explanatory variables are not greater than 0.5 , indicating that there is no serious multicollinearity problem. The fact is conducive to the following regression analysis.

Table 1. Descriptive statistics and correlation analysis results of research variables

\begin{tabular}{|c|c|c|c|c|c|c|c|c|c|c|c|c|}
\hline Variables & Mean & Std. & 1 & 2 & 3 & 4 & 6 & 6 & 7 & 8 & 9 & 10 \\
\hline 1.ROE & 0.074 & 0.119 & 1 & & & & & & & & & \\
\hline 2.FEP & 0.157 & 0.098 & -.007 & 1 & & & & & & & & \\
\hline 3.FS & 21.583 & 1.374 & $.235^{* *}$ & $-.117^{* *}$ & 1 & & & & & & & \\
\hline 4.FA & 12.250 & 4.951 & $-.074^{* *}$ & $.217^{* *}$ & $.199^{* *}$ & 1 & & & & & & \\
\hline 5.CDU & 0.130 & 0.338 & .015 & $.084^{* *}$ & $-.077^{* *}$ & $-.023^{*}$ & 1 & & & & & \\
\hline 6.RID & 0.364 & 0.049 & $-.031^{* *}$ & $.069^{* *}$ & $.048^{* *}$ & $.066^{* *}$ & $.046^{* *}$ & 1 & & & & \\
\hline 7.EC & 0.352 & 0.150 & $.109^{* *}$ & $-.103^{* *}$ & $.248^{* *}$ & $-.095^{* *}$ & $-.102^{* *}$ & $.028^{* *}$ & 1 & & & \\
\hline $8 . \mathrm{OS}$ & 0.610 & 0.487 & $-.045^{* *}$ & $-.148^{* *}$ & $.151^{* *}$ & $.087^{* *}$ & $-.172^{* *}$ & -.006 & $.282^{* *}$ & 1 & & \\
\hline 9.STET & 2.970 & 0.197 & $.077^{* *}$ & $-.219^{* *}$ & $.318^{* *}$ & $-.059^{* *}$ & $-.118^{* *}$ & $-.179^{* *}$ & $.041^{* *}$ & $.233^{* *}$ & 1 & \\
\hline 10.EEPG & 12.495 & 1.116 & $.239^{* *}$ & $.046^{* *}$ & $.414^{* *}$ & $.275^{* *}$ & $.059^{* *}$ & $.043^{* *}$ & -.015 & $-.044^{* *}$ & $.187^{* *}$ & 1 \\
\hline
\end{tabular}

Note: $\mathrm{N}=9416 ; * *$ and $*$ respectively represents significance level of 0.01 and 0.05

\subsection{Comparative Analysis Across Industries}

In this section, 9416 firm-year observations are divided into 14 sub-samples according to the industry type. The data of each sub-sample are respectively fitted with models(1).The regression results of the relationship between female executives and firm performance in different industries are shown in Table 2.

According to the regression results, it can be seen that there are significant differences among the impacts of female executives on corporate performance across different industries.

(1) There is zero effect of female executives on firm performance in 8 industries, including the Mining Industry, the Power, Heat, Gas and Water Production \& Supply Industry, the Real Estate Industry. When using ROA as the measure of firm performance, there is no significant difference in the results. Among the eight industries, except for the result in the Manufacturing Industry changes into a positive relationship, the zero results in the remaining seven industries still hold. The eight industries can be viewed as female-neutral industries, in which though female executives would not be treated in a discriminatory manner, they have no suitable platform to play their feminization roles with the females' specialized human capital or social capital. In such industries, the positive effects derived from gender diversity are offset by the negative effects gender conflict within the top management teams.

(2) Female executives in the Leasing and Business Services Industry, the Wholesale and Retail Industry, the Construction Industry, the Culture, Sports and Entertainment Industry have significant positive effects on performance.
Among the four female-friendly industries, female executives in the Leasing and Business Services industries have the most significant positive impact on corporate performance. The Leasing and Business Service Industry is an important part of productive service industry, which mainly provides services for production and business activities. The demands of these industries on executive skills are matched with the females' gender advantages, such as delicate mind, higher observation and communication capability, and original opinions on consumption trends. Therefore, in this kind of industry, the participation of female executives in corporate governance can bring diversified perspectives and ideas to corporate strategy and operation management, which is conducive to the correct decision-making of enterprises, thus promoting corporate performance.

(3) In the Information Transmission, Software and Information Technology Services Industry $(\beta=-0.148$, $\mathrm{P}=0.014$ ), female executives have a significant negative impact on corporate performance. Enterprises with different development prospects have different strategic decision-making and management methods to create value. Enterprises in high-growth industries intend to choose expansion strategies to help enterprises' rapid development, and enterprises in low-growth industries choose cautious strategies to help enterprises in maintaining their advantages or survivals in competition. The Information Transmission, Software and Information Technology Services Industry is a typical high-growth industry. In such an industry, in addition to strengthening their R\&D capabilities, the acquisition, integration and asset restructuring of the upstream and downstream enterprises in the same industry are also one necessary component of the company's strategic plans. Therefore, enterprises need managers who dare to 
take high risks. However, the psychological characteristics of women's risk aversion will make them more cautious and conservative when making decisions, which may hinder the development of high growth industries and reduce business performance.

Table 2. Regression results of FEM on ROE across various industries

\begin{tabular}{|c|c|c|c|}
\hline $\begin{array}{c}\text { Industry } \\
\text { Number }\end{array}$ & $\begin{array}{c}\text { Coefficients } \\
\text { of FEP }\end{array}$ & $\mathbf{P}$ & $\begin{array}{c}\text { Attitudes towards female } \\
\text { executives of the industry }\end{array}$ \\
\hline IN1 & -0.008 & 0.921 & Female-neutral \\
\hline IN2 & -0.013 & 0.752 & Female-neutral \\
\hline IN3 & 0.013 & 0.751 & Female-neutral \\
\hline IN4 & 0.143 & 0.048 & Female-friendly \\
\hline IN5 & 0.067 & 0.209 & Female-neutral \\
\hline IN6 & -0.088 & 0.322 & Female-neutral \\
\hline IN7 & 0.102 & 0.002 & Female-friendly \\
\hline IN8 & -0.096 & 0.400 & Female-neutral \\
\hline IN9 & 0.246 & 0.087 & Female-friendly \\
\hline IN10 & -0.148 & 0.014 & Female-discriminative \\
\hline IN11 & 0.014 & 0.289 & Female-neutral \\
\hline IN12 & -0.299 & 0.080 & Female-discriminative \\
\hline IN13 & 0.083 & 0.256 & Female-neutral \\
\hline IN14 & 0.350 & 0.000 & Female-friendly \\
\hline
\end{tabular}

\subsection{Robustness Test}

(1) The number of female executives (NFE) has been used as the measure of female executives' participation degree in Model(1), the empirical results still hold. (2)ROA has been used as the measure firm performance in Model(1), the empirical results holds. (3) $\mathrm{ROE}_{t+1}$ has been used to replace $\mathrm{ROE}_{t}$ in $\operatorname{Model}(1)$, and the empirical results cannot be rejected. Due to the limited paper length, the specific robustness test results have not been prescribed in detail.

\section{CONCLUSIONS AND IMPLICATIONS}

\subsection{Research Conclusions}

Taking the data of 856 Chinese listed companies consisting of 9416 firm-year observations over 2006-2016 as the research sample, the relationships between female executive and firm performance across different industries are addressed and compared. Empirical test and theoretical analysis come into the following conclusions:

On the topic of differences in female executives' performance consequences across industries, four female-friendly industries (i.e., the Leasing and Business Services Industry, the Wholesale and Retail Industry, the Construction Industry, the Culture, Sports and Entertainment Industry), eight female-neutral industries (i.e., the Mining Industry, the Power, Heat, Gas and Water Production \& Supply Industry, the Real Estate Industry, etc.) and two female-discriminative industries (i.e., the Information Transmission, Software and Information Technology Services Industry, the Accommodation and Catering Industry) are respectively identified. Most of female-friendly industries are end consumer-oriented, where the specialized leadership styles and management advantages of female executives, or in another words, gender stereotypes of female executives can perform better. In female-neutral industries, the positive effects of female executives nearly equal the negative impacts of female executives. Female-discriminative industries usually have features of high-growth and high-technology, where female executives' stereotypes of risk aversion or innovation avoidance would play their roles.

\subsection{Implications}

First, it is not a good choice to set a standardized gender quota for board of directors or the whole top executive teams. In different industries, female executives can play different roles. Second, according to their own industry characteristics, enterprises should promote the process of female executives' participation differently.

For the enterprises in the female-friendly industries, they should be committed to attracting and selecting high-quality female executives who are more consistent with the operation characteristics of the enterprise; For the enterprises in the female-discriminatory industries, they should be committed to identifying the potential practices of gender discrimination within the enterprise, and making practical corrections; For the enterprises in the female-neutral industries, they should be committed to learning and practicing the core skills needed for the operation of gender diversified teams and the cultivation of a female-friendly corporate culture.

\subsection{Limitations and Research Prospects}

The relatively smaller sample size used in this study remains as a limitation towards conducting further analysis in depth. Moreover, the differences of female executives' performance consequences among the sub-industries of the manufacturing industry cannot be reached in this study, since many of the sub-samples have no enough observations. In the future research, we should adopt the research samples that include a larger number of enterprises, a more comprehensive coverage of the industry.

\section{ACKNOWLEDGMENT}

This research was sponsored by the National Social Science Fund Project "Research On The Compensation 
Adjustment Effect Of Female Executives' Participation Degree In Corporate Governance And Its Performance Improvement Mechanism (20BGL147)".

\section{REFERENCES}

[1] Alexa A. Perryman, Guy D. Fernando and Arindam Tripathy. Do gender differences persist? An examination of gender diversity on firm performance, risk, and executive compensation. Journal of Business Research, 2016, vol. 69, issue 2, pp579-586.

[2] Moez Bennouri, Tawhid Chtioui, Haithem Nagati and Mehdi Nekhili. Female Board Directorship and Firm Performance: What Really Matters? Journal of Banking \& Finance, March 2018, pp267-291.

[3] Hiroaki Niikura and Miki Seko. The effect of inside and outside female directors on firm performance: Comparison of the First section, Second section, Mothers, and Jasdaq in the Tokyo Stock Exchange Market. International Journal of Economic Policy Studies, 2020, vol. 14, issue 1, pp123-166.

[4] Vandegrift, D., and Brown, P. Gender differences in the use of high-variance strategies in tournament competition. The Journal of Socio-Economics, 2005, Vol.34, Issue6, pp834-849.

[5] Changzheng Zhang, Qian Guo, Xin Mu. How Female Executives Affect Firm Performance? A Multi-approach Perspective. Advances in Economics and Business, 2016, vol. 4, issue 7, pp351-365.

[6] Amina Buallay. Sustainability reporting and firm's performance: Comparative study between manufacturing and banking sectors. International Journal of Productivity and Performance Management, 2019, vol. 69, issue 3, pp431-445.

[7] Aleksandr Kljunikov, Mehmet Civelek, Petrech and Jitka Kloudová. Entrepreneurial orientation of SMEs' executives in the comparative perspective for Czechia and Turkey. Oeconomia Copernicana, 2019, vol. 10, issue 4, pp773-795.

[8] Mario Daniele Amore, Orsola Garofalo and Alessandro Minichilli. Gender Interactions Within the Family Firm. Management Science, 2014, vol. 60, issue 5, pp1083-1097.

[9] Chirwa E W. Effects of gender on the performance of micro and small enterprises in Malawi[J]. Development Southern Africa, 2008, vol. 25, issue 3, pp347-362.

[10] Surendra P. Singh, Ruthie G. Reynolds and Safdar Muhammad. A Gender-Based Performance
Analysis of Micro and Small Enterprises in Java, Indonesia. Journal of Small Business Management, 2001, vol. 39, issue 2, pp174-182.

[11] Carmen Gallucci, Antonio D'Amato and Rosalia Santulli. Women on Board of Directors and Firm Performance: The Moderating Role of Female Ownership. Empirical Evidence from the Italian Wine Industry. Journal of Financial Management, Markets and Institutions, 2015, issue 2, pp225-244

[12] Pilar Giraldez-Puig and Emma Berenguer. Family Female Executives and Firm Financial Performance. Sustainability, 2018, Vol. 10, issue $11, \mathrm{pp} 1-15$.

[13] Emilia Peni. CEO and Chairperson characteristics and firm performance. Journal of Management \& Governance, 2014, vol. 18, issue 1, pp185-205.

[14] Jie Chen, Woon Sau Leung and Kevin P. Evans. Female board representation, corporate innovation and firm performance. Journal of Empirical Finance, 2018, vol. 48, issue C, pp236-254. 